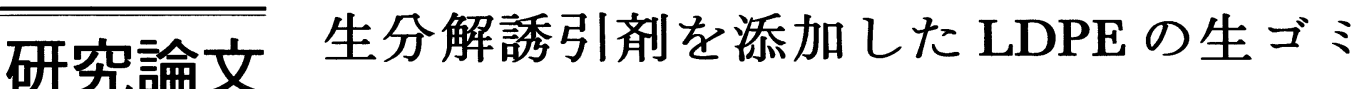 処理による劣化分解促進評価方法の研究
}

\author{
(平成 5 年12月 21 日 受理) \\ 大武 義人 $* 1 \cdot$ 小林 智子*1 $\cdot$ 伊藤 茂樹*1 $\cdot$ 浅部 仁志*2 \\ 矢吹 増男 $* 2 \cdot$ 村上 信直 $* 3 \cdot$ 小野 勝道 $* 4$
}

\begin{abstract}
要 旨 LDPE に生分解を誘引する成分を添加したポリマーの生分解性評価を行うために, 生ゴミ槽を用 いた促進評価試験を行い, 平山山林土裹埋設の場合との比較検討をした，その結果，わずか数カ月の生ゴミ 処理後に, 試料表面に菌系, 胞子の存在が相当認められ, 微生物活動の激しさがらかがえる. また, 処理試 料表面には生ゴミ成分の一部が移行生成したパルミチン酸カルシウムが, 部分的に付着していた. 引張強度 は平山山林土䁃で処理した場合よりも著しい低下を示すが，これは FT-IR でみられるカルボニル基の吸収 の増加に対応し酸化劣化が進行していることを示唆している．また，生分解を誘引する成分を含まない LDPE に打いてもかなりの引張強度の低下がみられる. したがって, 添加物のみならずLDPE の生分解が 起こっていることは確実である。このように, 生ゴミ処理は顕著に生物劣化分解を促進することが明らかと なった。これらの結果は，野菜等に含まれる脂肪酸が処理試料中に侵入し，その周辺での微生物活動を活発 にし，LDPE 自身の微生物分解を促進させていることが GC-MSによる分析や，ESR 測定により明らかに された.
\end{abstract}

\section{1. は じめに}

生分解プラスチックスの評価試験は活性污泥法 や酵素浸漬試験等 ${ }^{1}$ 種々存在するが，一般に行わ れている使い捨て用プラスチックスの廃棄を考え た場合, 土壌埋設法が最も現実的で自然に近い評 価方法であるといえるだろう。しかし，土畩埋設 法では一連の劣化, 崩壊, 分解に至る速度が, 濃 縮された特定微生物環境におかれている場合に比 べ非常に遅い. 特に, 現在著者らが研究開発を進 めているLDPE に澱粉, 分解誘引剂等を添加し た生分解プラスチックスの場合, LDPE 自体が難 分解性ポリマーであるためポリマー自体の分解に 至るまでの速度はさらに遅い，そのため, 劣化,

†本報を「LDPE の生分解性 (第 7 報)」とする.

*1 財団法人化学品検查協会 高分子技術部技術課 （宁131 東京都畦田区東向島 4-1-1)

*2 萩原工業株式会社 ヘギライン事業本部開発課 (宁712 岡山県倉敷市水島中通 1-4)

*3 株式会社竹中工務店 技術研究所 （宁270-13 千葉県印旛郡印西町大塚1-5）

*4 茨城大学工学部物質工学科

（于316 茨城県日立市中成沢町 4-12-1）
分解効果を評価するための処理期間が長くなり LDPE 生分解誘引剤の開発, 改良を行っていく上 で致命的障害となっている。したがって，なんら かの促進試験法を用いて評価期間の短縮をはかる 必要がある.さて，32 37年間微生物活動が活発 な土壤に埋没していた LDPE フィルムは約 $15 \%$ の重量減少が観察されたが2), この結果から単純 計算すると厚さ $60 \mu \mathrm{m}$ の LDPEフィルムが生分 解消隇するまでには，おおよそ300年間要するこ とになる。もし，60 $\mu \mathrm{m}$ よりも厚いフィルムや， モールド成形品であるならば LDPE の生分解反 応は土壌との接触表面反応であるため, 更に長時 間を要するであろう. LDPE は分解しない，もし くは難分解性といわれる根拠はここにある. とこ ろが，PE の生分解機構は exogeneous な反応ばか りでなく endogeneous な反応も起こること，その ため分子鎖に沿って分解の起点となる活性点を設 けることが分解反応促進化の手段であることが我 々によって解明されている2).このような現況を ふまえると, LDPE に対し人為的な劣化と微生物 劣化を併発させて分解に至る時間を短縮させる方 策を考兄 ${ }^{3)}$, それに基づく促進試験法の開発を検 討する必要がある，従来のポリマーに対する生分 
解促進試験法として報告されているものは西山 ら4)が提案したように，対象ポリマーを分解する 菌種を純粋培養した試験管中へ投下し，水分 $50 \%$ にして分解を促進した例5)，あるいは，Griffinに よる実験室レベルのゴミ処理装置に, 水, オリー ブ油, 砂糖, ポテトスターチを加えた人工生ゴミ を投入し，装置全体を回転し空気とよく混じり合 らようにして促進化を試みている例がある6). 生 分解の促進は媒体に微生物が関与する酵素酸化反 応であるため, 通常の劣化反応のように加温すれ ばすぐに劣化分解反応が早まることにはならな い. 例えば，著者らはホットポットテスト7)によ って $40,60,80^{\circ} \mathrm{C}$ の土壌を用いた加温試験を試み

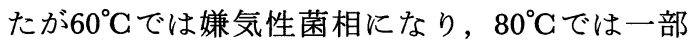
の嫌気性菌を除いては死隇してしまうことを確認 している.これらの結果を踏まえて, 新しく考案 した生ゴミを用いた促進試験法について報告する．

\section{2. 実験}

\section{1 促進処理装置}

Fig. 1 に示すような生ゴミを入れた槽を作成， 生ゴミの間に空気を曝気できるように小さな通気 用の穴がいくつも開いた塩ビパイプを通した。空 気の送風流量は約 $100 \mathrm{l} / \mathrm{min}$ として, 処理中の全 期間を通じて一定である．送風空気はろ過せず， 直接外気を用いた。送風前に生ゴミ槽より発生し ていた異臭は GC-MS で分析した結果メルカプ タン等であることが確認されたが，送風を開始す ることによりこれらの嫌気性雾囲気における異臭 は泳涂去できた。 そして，一年中を通して生ゴ ミ槽を PE 製透明シートで覆い, 温室効果により 槽内の温度を $30 \pm 5^{\circ} \mathrm{C}$ に保つょらにした。これ は, 微生物の増殖温度域の最も中庸の温度が保た れることを目的とした。この温度領域では Bacillus megaterium (巨大菌), Bacillus subtilies(枯草 菌), Escherichia coli(大腸菌) 等の存在が知られて いるが，お括よその菌は最低増殖温度, 最高増殖 温度の限界值に入る ${ }^{8)}$ 。冬期には, 温室効果のみ でチャンバー内の温度を保つことは不可能なた め, 稲ワラをのせて米ヌカ, 䳕フンを混合して発 酵を促し, 発酵生成熱により夏期の温度に近い $30 \pm 5{ }^{\circ} \mathrm{C}$ 保つょうにした. 槽内温度は試料設置 部付近より自動記録計でモニターした。評価試料 は曝気パイプより上に設置し, いずれの試料も新 鮮な生ゴミに充分接するようにした。 また，試料

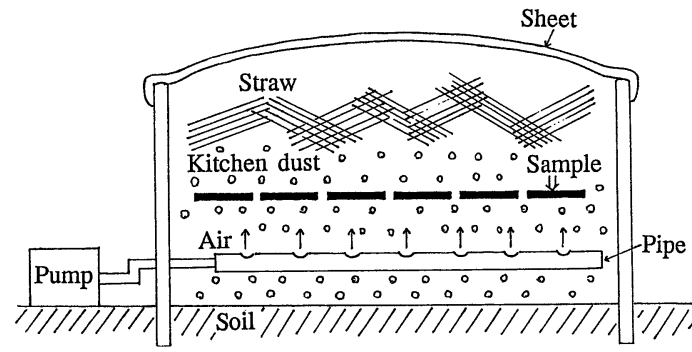

Fig. 1 Schematic representation of the chamber for the biodegradation of LDPE

設置場所による処理のバラッキを防ぐため，異な った 2 カ所に設置して比較を行った。稲ワラの利 用は当初, 上記に示した様に生ゴミ処理槽の保温 効果を目的としたが, 出口9)の研究ではリグニン 分解菌 IZU-154株が PE を分解することを見出し ている．とすれば，木材よりも多くリグニンを含 有する稲ワラの発酵分解菌の中にはPEを分解す るリグニン分解菌が存在する可能性を考慮しても よいのではないかと考えられる。このため, LDPEの劣化分解の促進性はより速をる可能性も ある。

\section{2 試料}

市販エコスターインターナショナル社製マスタ 一バッチ(商品名：エコスター, 販売 : 萩原工業 株式会社, 以下澱粉等添加マスターバッチ EC と 称す) $20 \%$ に添加剂を含まない日本石油化学株式 会社製 LDPE-F31Nを80\%ブレンドしたものと， LDPE 単体の 2 種類を用い, 厚み約 $60 \mu \mathrm{m}$ のフィ ルムにブロー成形した. 成形条件は押出機 $30 \phi$, $\mathrm{L} / \mathrm{D}=24$ ，ブロー比1.0である. 用いたマスター バッチの組成は, 澱粉が $36 \%$, 植物油が $8 \%$ 添加 されたものである10).

\section{3 比較のための平山山林土壤および砂への 埋設}

生ゴミ処理法と通常の土壤埋設処理法促進性に ついての比較を行らために，平山山林土壤および 砂を用いた埋設評価も同時に進行させた．埋設に 用いた平山山林土䁃の化学分析(分析方法は前 報10) 飞従った)，微生物の同定結果を Table 1 亿 示す(方法はバージスマニアル法に基づいて行っ た)。この結果, 平山山林土壤では通常の土壤 ${ }^{11)}$ に比べ微生物活動が優れていることが確認され た。使用した砂については有機物执よび微生物の 存在がほとんど認められなかった。埋設期間はい 
Table 1 Analysis of coppice soil (i) Chemical analysis ${ }^{* 1}$

\begin{tabular}{lc}
\hline \multicolumn{1}{c}{ Items } & Analytical results ${ }^{* 2}$ \\
\hline $\mathrm{pH}\left(\mathrm{H}_{2} \mathrm{O}\right)$ & 5.0 \\
$\mathrm{pH}(\mathrm{KCl})$ & 4.5 \\
Moisture content \% & 83.0 \\
Water content \% & 45.3 \\
Organic matter \% & 11.0 \\
Inorganic matter \% & 43.7 \\
\hline *1 Tests are based on the standard of soil engineering \\
society \\
*2 Indicated in \% per fresh soil $1 \mathrm{~g}$
\end{tabular}

(ii) Number of microorganism

\begin{tabular}{lc}
\hline Items & Number of microorganism ${ }^{* 3}$ \\
\hline Viable cell/g & $8.8 \times 10^{6}$ \\
Unaerobes/g & $6.4 \times 10^{5}$ \\
Clostridia/g & $5.0 \times 10^{4}$ \\
Eumycetes/g & $7.8 \times 10^{6}$ \\
\hline
\end{tabular}

${ }^{* 3}$ Numbers per fresh soil $1 \mathrm{~g}$

(iii) Identification of microorganisms

\begin{tabular}{ll}
\hline Eumycetes & Penisillium sp \\
Mucor sp \\
Bacteria & Bacillus subtilis \\
& Bacillus cereus \\
& Bacillus cereus ver mycoides \\
& Clostoridium sp \\
& Pseudomonas sp \\
\hline
\end{tabular}

ずれの埋設も最長 1 年間とした.

\section{4 評価方法}

生ゴミ, 土壌埋設処理前後の試料の評価は(1)

外観観察 (2) 引張試験 (3) 分子量および分子 量分布測定 (4) 顕微鏡 FT-IR 分析 (5) 蛍光 $\mathrm{X}$ 線分析 (6) エチルェーテル抽出量および抽 出物の GC-MS 分析 (7) DSC による酸化開始 温度の測定以上(1) (7)の測定項目は, LDPE の生 分解性第 2 報に従った ${ }^{12)}$ 。 (8) ESRによるフリ ーラジカル発生量の測定 (日本電子製 JES-FEX)

\section{3. 結果および考察}

\section{1 目視およびSEMによる外観観察}

3.1 .1 平山山林土壤10週間埋設処理 LDPE 単体の場合，外観上の変化は認められない，EC 添加 LDPE においても同様であった. SEM にて

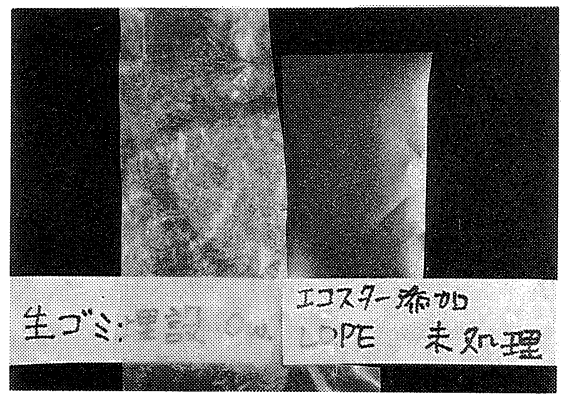

Photo 1 Appearance of kitchen dust treated LDPE blended with EC for 10 weeks and untreated LDPE blended with EC

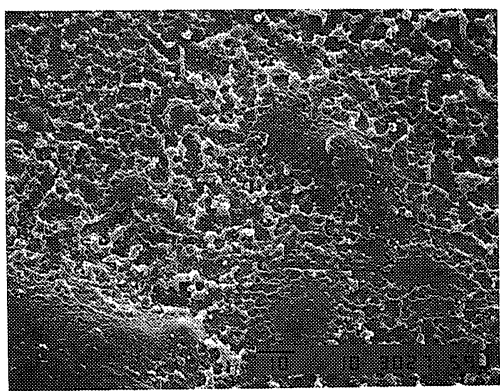

Photo 2 SEM photograph of EC added LDPE treated with kitchen dust for 10 weeks $(\times 500)$

部分的にフィルム表面近傍の澱粉粒子を覆ってい たポリマーが破壊されて空孔のできている状態が わずかに観察できる.

3.1 .2 生ゴミ10週間埋設処理 無添加 LDPE はフィルム表面に白い付着物が認められる。その ため，フィルムは半透明状となっている. 水洗し ても付着物は落ちない. EC 添加 LDPE において もフィルム表面が白濁し(Photo 1)，その様子は 無添加 LDPE よりも激しい。白濁部の SEM 観察 を行らと, 付着物の存在が無添加 LDPE, EC 添 加 LDPE (Photo 2) 両者に認められる。また， EC 添加 LDPE の表面近傍の澱粉粒子のほとんど が消隇し，クレーター状の空孔ができていた。 そ の周辺には真菌 (糸状菌)のような微生物の存在が 見られた (Photo 3,4). 土䁃中に普遍的に存在す るものとしてペニシリウム属やアスペルギルス属 があり, Photo 3 はその形状からペニシリウム属 であると考えられる. また，Photo 4 亿示すよう に子のら胞子の形状からもペニシリウム属の可能 性が高いと考えられる.これらの現象は, 無添加 


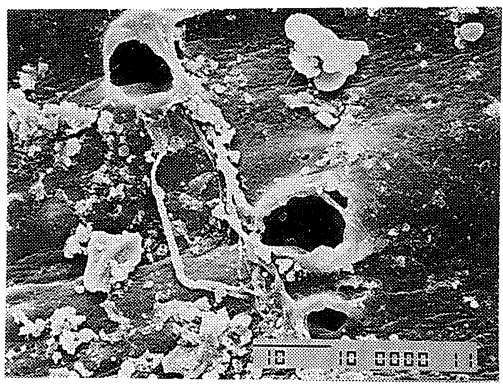

Photo 3 SEM photograph of EC added LDPE treated with kitchen dust for 10 weeks $(\times 2000)$

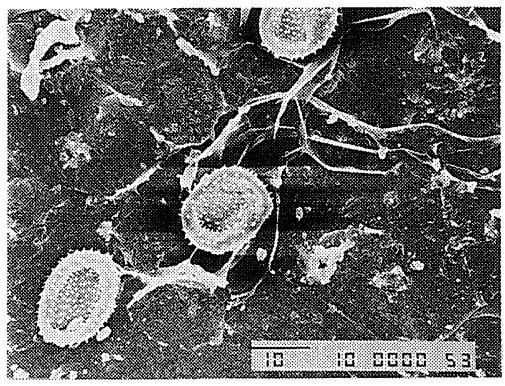

Photo 4 SEM photograph of EC added LDPE treated with kitchen dust for 10 weeks $(\times 1000)$

LDPE フィルムでも少なからず認められる. 以上 の表面観察結果から, 生ゴミ処理により, 平山山 林土壌よりも激しい劣化が括こり, フィルム表面 上に付着した異物の存在の他, 菌系, 胞子が無数 に付着し, LDPE 表面上での微生物活動の激しさ がうかがえる。

\section{2 引張試験, 分子量分布測定}

破断伸びの低下率と処理時間との関係を Fig. 2 に示す. 生ゴミ処理は平山山林埋設と比べて, 無添加 LDPE, EC 添加 LDPE とも著しい低下を 示す. この傾向は, 処理 4 週間程で既に大きな有 意差となって現われる，砂埋設においては，泀と んど変化は認められない, 重要な点は, 生ゴミ処 理により無添加 LDPE でも著しい伸び率の低下 が認められることである.すなわち, 生ゴミ処理 により澱粉ばかりでなく LDPEの劣化も激しく おこっていることが推察される.

LDPE の分子量は，物性に大きな変化が認めら れたにもかかわらず, 生ゴミ, 平山山林土壤処理 のいずれの場合にも処理32週間でほとんど変化は 認められなかった. FT-IR 測定でも主鎖切断を

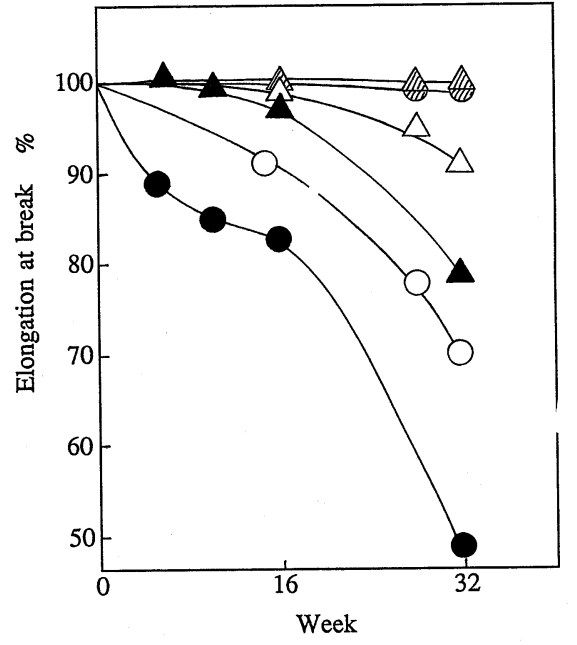

Fig. 2 Relationship between treating time and elongation at break. The elongation at break is given by the relative value (\%) against the untreated sample

- LDPE + EC (in kitchen dust)

$\triangle$ LDPE (in kitchen dust)

OLDPE + EC (in coppice soil)

$\triangle \mathrm{LDPE} \quad$ (in coppice soil)

- LDPE+EG (in sand)

$\triangle \mathrm{LDPE}$ (in sand)

誘引すると考えられる $-\mathrm{C}=\mathrm{C}-\left(1640 \mathrm{~cm}^{-1}\right)$ の吸 収 ${ }^{2)}$ は生ゴミ, 平山山林土壤処理両試料ともわず かに認められる程度であるため, この処理期間内 ではまだ全体的な分子量の変化には至らないと考 えられる。

\subsection{FT-IRによる澱粉とオイルの減少量測定}

澱粉添加マスターバッチ ECを $20 \%$ 添加した LDPE には澱粉が $7.2 \%$ ，オイルが1.6\%含有され ている.これらの添加物は土壌埋設中に, 澱粉は 主にアミラーゼによって分解し，フィルムに空孔 を生じ機械的強度を弱める。 また，オイルは既に 明らかにしたよらにポリマーの劣化を促す役目を 担い, ポリマー鎖の endogeneousな分解を生じさ せる一種の触媒的な存在と考学られる. そのた め, これらの添加物の減少をみることは物性の低 下や劣化進行の程度をみる目安にもなる。澱粉は $990 \mathrm{~cm}^{-1}$ のエーテル結合を，またオイルは1745 $\mathrm{cm}^{-1}$ のエステル基を用いて, $1470 \mathrm{~cm}^{-1}$ のメチ レン基のピークを基準にして行った。なお，エス テル基の吸収強度はカルボニル基の吸収全体にべ 


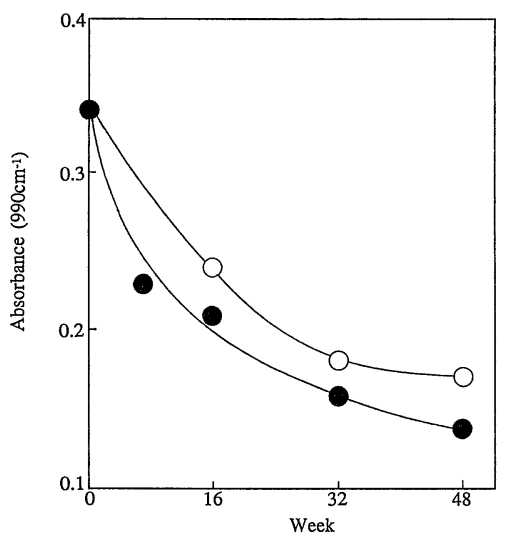

Fig. 3 Intensity of characteristic starch band (990 $\mathrm{cm}^{-1}$ ) of FT-IR plotted against time

- treated with kitchen dust, $\bigcirc$ treated with coppice soil

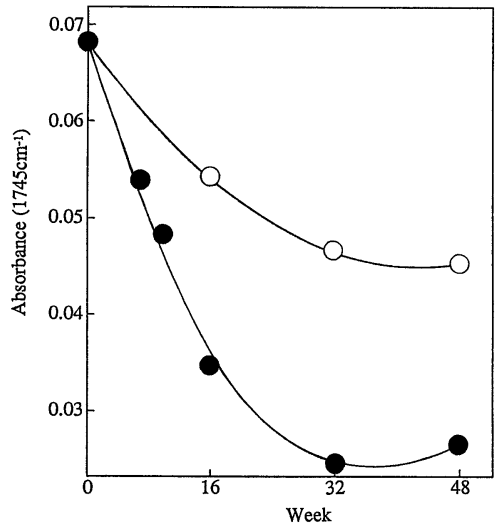

Fig. 4 Intensity of characteristic oil band $\left(1745 \mathrm{~cm}^{-1}\right)$ of FT-IR plotted against time

- treated with kitchen dust, $\bigcirc$ treated with coppice soil

ースラインを引いて求めたもので，エステル基の 強度の他のカルボニル基からの寄与も含んでい る. 結果を澱粉についてはFig. 3 に，オイルに ついてはFig. 4 に示した。これらの結果より， 生ゴミ処理は平山山林土壤埋設に比べ搌粉，オイ ルの消費を促していることが確認された．澱粉の 消費は先の SEM 観察の結果と一致する。一方, オイルのエステル基の吸収は処理 3 カ月までは減 少カーブを示すが， 3 カ月以上では逆に上昇傾向 を示す。これは，ポリマーの劣化によりカルボニ

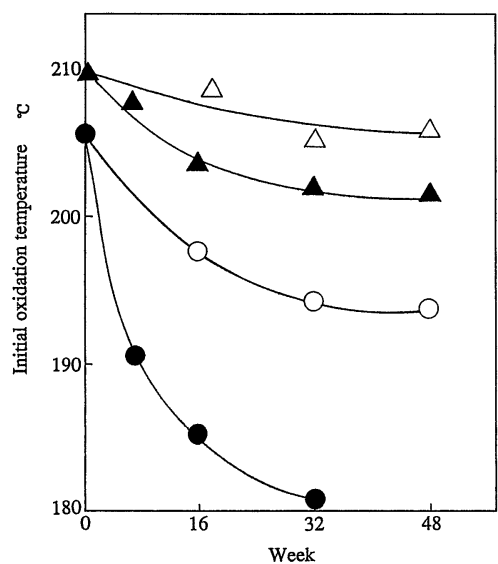

Fig. 5 The relationship between initial oxidation temperature and treating time

- LDPE blended with EC, $\triangle$ LDPE (treated with kitchen dust)

O LDPE blended with EC, $\triangle$ LDPE (treated with coppice soil)

ル基の吸収が増加するためと考えられる。

\subsection{DSC，FT-IRによる劣化度の測定}

ポリオレフィンの酸化が進行するほど酸化開始 温度が低下する現象吕)を利用して，DSCにより 急激に生ずる酸化発熱点(酸化開始温度)を測定し た(Fig. 5)。 その結果, 無添加 LDPE, EC 添加 LDPE のいずれの場合も生ゴミ処理試料は平山山 林土壤処理試料よりも著しい酸化発熱点の低下が 認められた. 特に, EC 添加 LDPE の生ゴミ処理 試料の場合が著しい，FT-IR による劣化度につ いては $1710 \mathrm{~cm}^{-1}$ (カルボン酸)の吸収に注目し $1470 \mathrm{~cm}^{-1}$ のメチレン基の吸収を基準として定量 を行った（Fig. 6)。吸収強度は前述のエステル基 の場合と同様に行った。この結果, 生ゴミ処理に 打ける EC 添加 LDPE ではこの吸収が顕著な増 加を示した。一方，平山山林土㙥試料での増加は 少なく, 生ゴミ処理試料の $1 / 3$ 程度であった。こ の傾向は，無添加 LDPE でも同様に認められた． この結果から，生ゴミ処理は澱粉ばかりでなく LDPE の劣化をも促進していることが確認された.

\section{5 フィルム表面付着物の分析}

3.1で示した生ゴミ処理試料には平山山林土畩 埋設試料ではみられない白色物が表面に付着する (Photo 1,2). 特に, ECの添加されたLDPEで は著しかったが，LDPEのみでもその現象は少な 


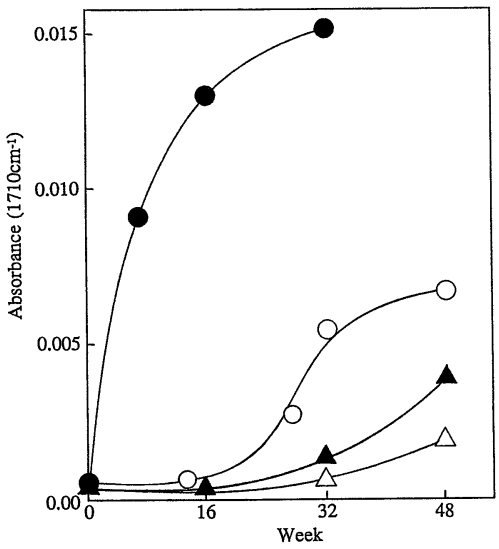

Fig. 6 Increase of carbonyl band intensity (1710 $\mathrm{cm}^{-1}$ ) with treating time

- LDPE blended with EG, $\triangle$ LDPE (treated with kitchen dust)

○ LDPE blended with EG, $\triangle$ LDPE (treated with coppice soil)

からず認められた，白色付着物の定性分析は，よ り付着物の多いEC 添加 LDPEを用いて行った. 得られた FT-IR 顕微反射スペクトルを Fig. 7 に 示す. $1530 \mathrm{~cm}^{-1}$ と $1580 \mathrm{~cm}^{-1}$ に鋭いピークが認 められ，脂肪酸の金属塩すなわちパルミチン酸カ ルシウムの標準チャートとほぼ一致した。更に は，この白色部をミクロスパーテルで慎重に剝離 し, $3 \mathrm{~N}-\mathrm{HNO}_{3}$ で溶解, エチルェーテル抽出を行 いGC-MS 分析を行った結果，パルミチン酸の 存在が確認されると同時に, 蛍光 $\mathrm{X}$ 線により $\mathrm{Ca}$ の存在が確認されたことから白色付着物には パルミチン酸カルシウムが含まれている。これ は, 生ゴミ中の野菜等に含まれている $\mathrm{Ca}, \mathrm{K}$ 等 の一部が同様に野菜中に多量に含まれる飽和脂肪 酸と処理中に結び付いた結果生じたものと考えら れる. また，同時に蛍光 $\mathrm{X}$ 線により $\mathrm{P}, \mathrm{S}$ 子検出 された。微生物細胞の構成元素として炭素, 酸 素, 窒素, 水素そして乾物量比としてリン $(\mathrm{P})$ や 硫黄 $(\mathrm{S})$ がそれぞれ $3 \%, 1 \%$ 含まれている。その ため, 本分析の結果検出された $\mathrm{P}, \mathrm{S}$ の元素の存 在は試料周辺での激しい微生物活動を示唆するも のであろう.

\section{6 フィルム中のエチルエーテル抽出物の分 析}

無添加 LDPE の生ゴミ処理を行った場合, パ

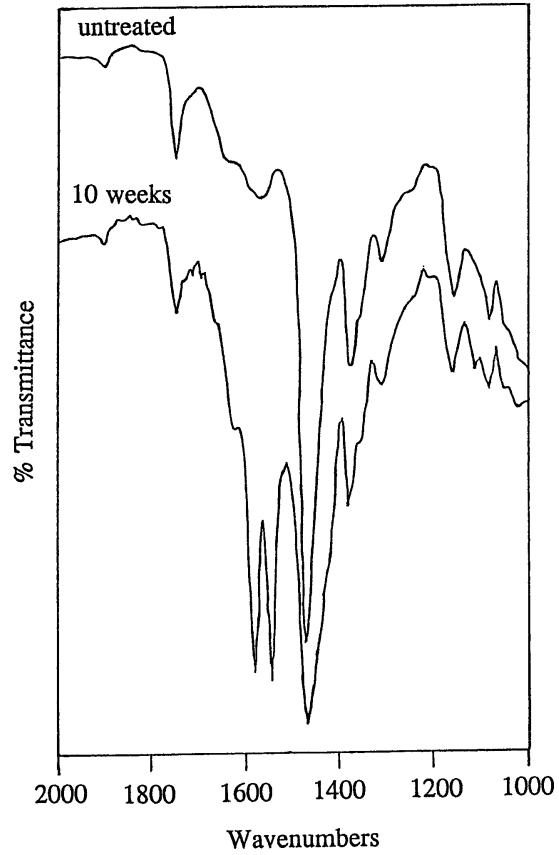

Fig. 7 FT-IR spectra of surface EC added LDPE treated with kitchen dust

ルミチン酸カルシウムが認められない透明な部分 もある。これら透明な部分を切りとり，エチルェ ーテル抽出を行った. 無添加 LDPE の平山山林 土壤 8 力月埋設処理したものと, 未処理 LDPE を比較対象試料として同様に抽出し， 3 種類の抽 出物について GC-MS 分析を行った。抽出量を Table 2 に示す. 生ゴミ処理は未処理に比べて抽 出量が多く, 平山山林土壤に比べると倍以上の抽 出量になる. 一般に, 土壇埋設処理は劣化分解の 再現性に乏しいことが指摘されている(14)ため，フ ィルムの 3 カ所の異なる部分での抽出を行った が，いずれも同じ傾向が得られた. Table 3 にエ チルェーテル抽出物の GC-MS 分析結果を示す. 比較対象として同時に行った無添加 LDPE の未 処理, 平山山林土壤処理試料で検出されたものに ついてはカットし, 生ゴミ処理特有なものに限定 した。検出量の最も多かったものはパルミチン 酸, 次いでステアリン酸, オレイン酸の順にな る.これらの検出物質は代表的な脂肪酸で動植物 に広く分布し，生ゴミ中に埋設されている間に多 量に含まれていた水分は脱水され, 脂肪酸等が濃 縮し，LDPE 中に移行したと考えられる．これら 
Table 2 The volume of ethyl ether extract (LDPE)

\begin{tabular}{lc}
\hline \multicolumn{1}{c}{ Items } & Ethyl ether extract \% \\
\hline Kitchin dust treatment 8 month & 0.95 \\
Original (Non treatment) & 0.60 \\
Coppice soil treatment 8 month & 0.41 \\
\hline
\end{tabular}

Table 3 Analysis of solvent extraction by GC-MS from Kitchin dust treatment LDPE

(1) 2,6- $\mathrm{Di}$ (1-1 dimethyl ethyl)-4methyl phenol

(2) Dodecanamide

(3) Tetradecanoic acid

(4) Hexadecanoic acid

(5) Hexadecanoic acid ethylester

(6) Heneicosane

(7) 9-Octadecanoic acid

(8) Octadecanoic acid

(9) Bis (2-ethylhexil) phtalate

の脂肪酸は LDPE との親和性をもつと同時に, 極性のカルボキシル基をもつために微生物との親 和性も高く, LDPE の微生物分解の促進に打いて 重要な働きをしているものと思われる．よく知ら れているように，脂肪酸は $\boldsymbol{\beta}$ 酸化によってアセ チル $\mathrm{C}_{0} \mathrm{~A}$ を生じ, TGA 回路によって $\mathrm{CO}_{2}, \mathrm{H}_{2} \mathrm{O}$ に酸化されるため, 脂肪酸の存在は微生物の繁殖 をうながし，近傍に存在する $\mathrm{PE}$ 鎖に対する微生 物分解の活性化をも促進するのであろう。

\section{7 過酸化物とラジカルの生成}

Griffin らはLDPEフィルムの生ゴミ処理を行 った際に過酸化物が生成していることを報告して いる6). 無添加 LDPE の生ゴミ処理試料をエチル エーテル抽出し, その抽出物について FT-IR ス ペクトルを測定した. 結果を Fig. 8 に示す. 1 年 間処理後には $3600 \mathrm{~cm}^{-1}$ に OOH の吸収がみられ ると同時に, $3400 \mathrm{~cm}^{-1}$ 付近のブロードな $\mathrm{OH}$ の 吸収が増加して扣り, 過酸化物(打そらくハイド ロパーオキサイド)がかなり生成していることが 示唆される. 過酸化物の分解によるラジカルの発 生を確認するためにエコスター無添加 LDPE の ESR の測定を行った (Fig. 9). 得られたブロード な ESR シグナルは，半値幅が大きいことから埋 設中に土壇や生ゴミよりポリマー中に浸透した遷 移金属イオンによるものと思われる。これら遷移 金属イオンは, LDPEのポリマーラジカルの発生
Table 4 Values calculated from the ESR spectra of kitchin dust treatment, coppice soil treatment and non treatment

\begin{tabular}{lc}
\hline \multicolumn{1}{c}{ Sample } & $\begin{array}{l}\text { Intensity PtoP/ } \\
\text { sample weight }\end{array}$ \\
\hline Non treatment & 360 \\
\hline $\begin{array}{l}\text { Coppice soil } \\
\text { treatment } 3 \text { month }\end{array}$ & 708 \\
\hline $\begin{array}{l}\text { Kitchin dust } \\
\text { treatment } 3 \text { month }\end{array}$ & 1020 \\
\hline $\begin{array}{l}\text { Kitchin dust } \\
\text { treatment } 7 \text { month }\end{array}$ & 1270 \\
\hline $\begin{array}{l}\text { Kitchin dust } \\
\text { treatment 8 month } \\
\text { after ether extraction }\end{array}$ & 1560 \\
\hline
\end{tabular}

をフェントン反応により促していると考えられ る15). Table 4 に単位重量当りのシグナル強度を 示す. シグナル強度は未処理, 平山山林処理, 生 ゴミ処理の順に増加し，また生ゴミ処理時間が長 いものほど大きくなった．生ゴミ処理試料では LDPE 表面で生ゴミより移行した脂肪酸の微生物 分解がおこると同時に，遷移金属イオンを介した LDPE 自身の分解が活発におこるものと思われる.

RO・ラジカルやヒドロキシラジカルは寿命が極 めて短いため定常濃度が低く, ESR シグナルに 現れないが，遷移金属イオンの生成が確認された ことから，これらのラジカルは極めて多く現われ ているものと考えられる．以上の結果はすでに報 告したように，条件さえ整えば高分子量 LDPE が微生物分解し，かつ分解を促進する添加剂の存 在下では著しく分解速度が増大することを示して いる.

\section{4. と め}

LDPE は難分解性ポリマーであるため，微生物 分解の速度は脂肪酸エステル系等の易分解性ポリ マーと比較し極めて遅い，そのため，種々の分解 誘引剂を添加するとともに，生ゴミ処理による生 物劣化の分解促進試験を行い生ゴミの促進効果お よび添加した誘引剤の有効性について検討を行な った結果，次の結論が得られた.

(1) 生ゴミ処理後の LDPEフィルムは表面に菌 系や胞子の存在が相当数認められ, 微生物活動の 激しさがうかがえる。 また，試料表面には生ゴミ より移行，生成したと考兄られるパルミチン酸カ 


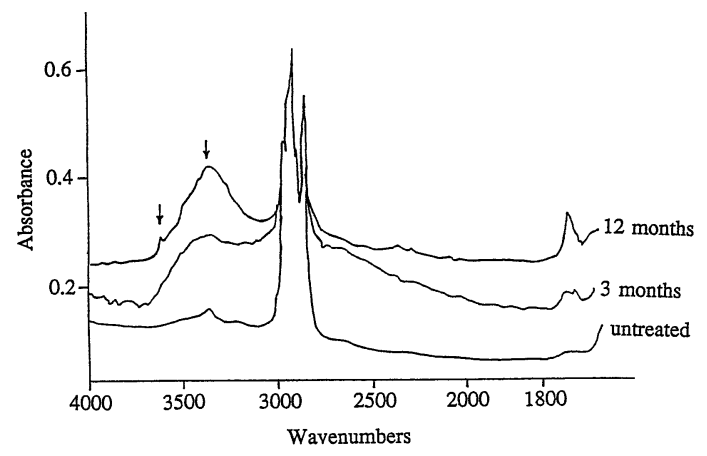

Fig. 8 FT-IR spectra of solvent extract of kitchen dust treated LDPE

ルシウムが部分的に付着している. 平山山林土壤 ではこのような現象は見当らない。

(2) フィルムの引張強度は平山山林土壤処理試料 にくらべ著しい低下を示す．特に，エコスター添 加 LDPEでは顕著であった。 また，砂埋設試料 では強度変化が認められない。この結果は, FTIR で得られたカルボニル基の吸収の増加と対応 する.

(3) (1)〜(2)の結果は, 平山山林土壤では微生物の 影響, 生ゴミ処理では生ゴミ中に含まれる脂肪酸 が処理試料表面に移行し, 微生物活動が活発化し た結果 LDPEの劣化を促進しているものと考兄 られる。

(4) 微生物はパルミチン酸, ミリスチン酸等の飽 和脂肪酸を体内に含むが8)，それらの存在は増殖 の要因となる可能性が高く, 生ゴミ処理の結果脂 肪酸を含浸した LDPE は, 微生物活動がしやす い状態になりポリマーの劣化と相乗し, 酵素分解 反応を促進していることが考えられる.

[附 記] 本研究の一部は, 日本ゴム協会, 第60 回通常総会研究発表講演会(於久留米リサーチパ 一ク，1993年 5 月21日)に拈いて発表したもので ある.

\section{文献}

1）大武義人他：「第 2 世代に入った生分解プラスチッ ク」, 大阪ケミカルマーケッティングセンター, P. 25 33, (1993)

2）大武義人 - 小林智子 - 伊藤茂樹 - 浅部仁志 - 矢吹 増男・小野勝道 : 日ゴム協誌, 66, 504 (1993)

3）大武義人 · 小林智子 · 伊藤茂樹 · 山本愉香 · 浅部

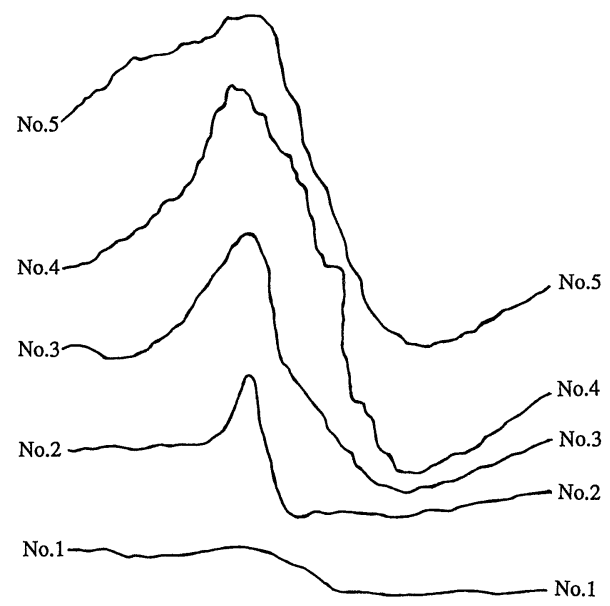

Fig. 9 ESR spectra biodegraded LDPE

No. 1: untreated

No. 2: treated with coppice soil for 3 months

No. 3: treated with kitchen dust for 3 months

No. 4: treated with kitchen dust for 7 months

No. 5: treated with kitchen dust for 8 months

志・矢吹増男 : 日本ゴム協会第 6 回エラストマー 討論会講演要旨集, P. 59 (1992)

4）西山昌史：平成 3 年度四国工業技術試験所研究発 表会資料「海洋資源の開発之利用」

5）土肥義治編：「生分解性プラスチックのおはなし」 日本規格協会, P. 147

6) G. J. L. Griffin: J. polymer Sci. Symposium, No. 57, 281 (1976)

7）大武義人 · 小林智子 ·五味洋子 · 伊藤茂樹 · 百武 健一郎・矢吹増男 : 日本ゴム協会第 4 回エラストマ 一討論会講演要旨集, p. 88 (1990)

8）高橋訳：「微生物学(The micro Biol World)」培風館 (1990), P. 191

9）出口哲也 : Polymer preprints, Japan, 42, No. 2, 427 (1993)

10）大武義人 ·五味洋子 - 小林智子 - 伊藤茂樹 - 百武 健一郎·矢吹増男 : 日ゴム協誌, 64 677, (1991)

11）大武義人 ·五味洋子 - 小林智子 - 伊藤茂樹 - 百武 健一郎・矢吹増男：日本ゴム協会第 4 回エラストマ 一討論会講演要旨集, p. 84 (1990)

12）大武義人・小林智子・五味洋子・伊藤茂樹 · 百武 健一郎・矢吹増男：日ゴム協誌，64,688（1991）

13）大武義人 - 小林智子.五味洋子. 伊藤茂樹：日本 ゴム協会第58回通常総会講演要旨集, p. 48 (1991)

14）矢可部芳州：合成樹脂, 39, 14, (1993)

15) Mizuta, Y., Mitsuta, K., Kohno, M.: Proceedings of the 4 th Biennial General Meeting of the Society for Free Radical Research, Kyoto, Japan, 9-13 April, 817820, (1988) 


\title{
ACCELERATION OF BIODEGRADATION OF LDPE ADDED WITH BIODEGRADATION INDUCING AGENTS BY BURIED IN KITCHEN DUST
}

\author{
Yoshito OHTAKE, Tomoko KOBAYASHI, Shigeki ITOH (Chemicals Inspection \& \\ Testing Institute, Sumidaku, Tokyo 131, Japan), Hitoshi ASABE, Masuo YABUKI \\ (Hagihara Indusrties, Inc., Mizushima, Kurashiki 712, Japan), Nobunao MURAKAMI \\ (Takenaka Co., Inzai-machi, Inba, Chiba 270-13, Japan), and Katsumichi ONO \\ (Department of Materials Science, Ibaraki University, Nakanarisawa-cho, Hitachi \\ 316, Japan)
}

In order to evaluate the biodegradability of the LDPE added with several degradation inducing agents, the LDPE film was buried in an composting chamber containing kitchen dust. After only several weeks of burial, a number of hyphae and spores observed on the surface of the film. This means the microbial activity is extremely high on the surface of the film. We detected calcium palmitate on the film surface. It is well known that the palmitic acid is an important constituent of kitchen dust. Thus we considered that the palmitic acid migrate from kitchen dust to film surface, and that this compound plays an important role in the acceleration of biodegradation of LDPE. The decrease of tensile strength of LDPE buried in kitchen dust was much faster than the one buried in coppice soil. The result seems to correspond the stronger FT-IR carbonyl band of the former. The decrease of tensile strength was evident even for the LDPE which does not contain any degradation inducing agents. Thus we concluded that the biodegradation of LDPE really proceeds in the compost composed from kitchen dust. It was suggested that the fatty acids included in vegetables migrate to film surface to promote the microbial activity, and to accelerate the biodegradation of LDPE chain. ESR spectra of the film showed that the radical concentration increased with the treating time with the compost.

(Received on December 21, 1993) 